\title{
Development Of An Internal Marketing Strategy For Faculty Of Nursing At Port Said University
}

\author{
${ }^{1}$ Ali Daifallah A. Abo Soliman, ${ }^{2}$ Prof. Neamat Mohamed El-sayed, ${ }^{3}$ Prof. SanaaAbd \\ El-azeem Ibrahim ${ }^{4}$ Dr. Rasha Ibrahim El-sayed Inany. \\ ${ }^{1}$ M.Sc. in Nursing Administration, Faculty of Nursing, kafr El-sheikh University. ${ }^{2}$ Professor \\ of Nursing Administration, Faculty of Nursing, Damanhur University. ${ }^{3}$ Professor of Nursing \\ Administration, Faculty of Nursing, Port Said University. ${ }^{4}$ Lecturer of Nursing \\ Administration, Faculty of Nursing, Port Said University
}

\begin{abstract}
Background: Human resources are the most valuable asset of organization. Therefore, organizations undertake to cost high for internal customers that lead to their satisfaction that results in developing the quality of products and services as well as achieving customer satisfaction.The aim: of this study is to develop an internal marketing strategy for faculty of nursing at Port Said University. Sample: the study is carried on all available internal customers of the faculty $(\mathrm{n}=378)$. Research design: An exploratory research designis utilized. Data collection tools: data are collected using three tools: to assess the availability of internal marketing elements for teaching staff, employees and nursing students, in addition internal marketing strategy as the fourth tool. Results: revealed that the most available element of the internal marketing among teaching staff, employees and students is the communication element, followed by supervision and scientific research support among teaching staff, supervision and safety measures among employees and supervision followed by achievement and rewards among students. Whereas, the lowest available element is the benefits among teaching staff, employees and students.Conclusion: availability of internal marketing elements at the faculty is moderately fulfilled. The highest mean score of it were among the teaching staff followed by students and employees. Recommendations: The study recommended that academic managers have to maximize their efforts and take the needed measures toward applying the developed internal marketing strategy.
\end{abstract}

Key words:Internal marketing, internal customer, teaching staff, students, employees. 


\section{INTRODUCTION}

Achieving competitive advantage and maintenance of it has become one of the most important organization challenges nowadays. Due to the growing trend of globalization, competition among organizations is more as well; therefore, identification and understanding of the impact of affecting factors on organization customer satisfaction has been more important for its managers and shareholders. So, organizational managers should consider that the survival and profitability depends on understanding and appropriate relationship with the around environment. They have to look for a way for the organization's internal and external factors and use current opportunity in order to achieve competitive advantage against their competitors (Yashar, Soleyman\& Hussein, 2013).

Organization which can develop its strategy will get a champion in competition and create satisfaction of both internal and external customers (Susanti, Sule\&Sutisna, 2015). It is clear that any sustainable competitive advantage for universities is via the staff (Shima\& George, 2014), Staff is the internal customers and in organization they have been called internal marketing (Falavarjani,Falavarjani\&Isfahani, 2013).Kokemuller (2015) defined internal marketing as the way an organization promotes its values and brand internally to employees that help generate its brand value, and is a management philosophy that believe that employees are "internal customers" that require motivation on organization policies. While,Shahzad\&Naeem (2013)stated that the perception of internal marketing developed from the thought that employees comprise an internal market within the organization in order to achieve the objectives of the organization.

Applying IM plays a vital role in realizing mission and objectives of the firm through two important parameters includes involvement and commitment which are prerequisites for motivated and engaged workforce;Attain strategic fit and coherence among organizational policies and processes; Achieving strategic, tactical and operational goals by bridging the gap between horizontal \& vertical linkages; Organizations successfully meet discrepancies and business challenges by establishing efficient communication channels to empower organizations to solve problems and functionalize it's actions (Ahmed \&Rafiq, 2003); Warraich, Awais, Parkash\& Ahmad, 2014).

Strategies and strategic steps to create a competitive organization have been important parts of market success. Internal customers represent one of the leading elements in 
building competitiveness due to their direct roles in organizations' market practice. Understanding the motivations of internal customers to deliver competitive performance in favor of organizational strategies is important for both executives and marketing scholars (Kanibira\&Nartb, 2012).The internal marketing implementation process may have a major contribution in improving human resources management by increasing labor productivity and workforce satisfaction. From a managerial perspective, internal marketing implementation may favor creating departments with real customer orientation, increasing customer satisfaction and implementing an efficient customer relation management and transitioning to a holistic marketing approach. From a marketing standpoint, internal marketing implementation can help build and strengthen brand equity, obtain higher return of investments, increase the benefits of marketing programs and decrease marketing costs (Cătălin, Andreea\& Adina, 2014).

Implementing of an internal marketing plan helps in educating, stimulating, guiding and leading workforce to higher levels of performance and gratification (Mishra, 2010). So, more attention should be given to organizations to implement internal marketing practices. Organizations should offer more training to marketing managers and other functional managers on internal marketing, this is important for all managers who manage teams of employees, and this is something that many managers in Egypt are lacking. It is important for marketing managers to work more closely with human resources managers in implementing internal marketing practices. It is also important for organizations to link internal marketing practices to employee performance and achievement and the overall organizational goals and objectives (Shamma, 2012).

Internal marketing mix delineates components like reward/compensation, internal communication, supervisor/senior leadership, intangible benefits and intermediary that facilitate internal customers to understand and focus on business performance through servicing profitable customers (Mutharasu, Natarajan\& Filipe, 2013). A proper definition of elements of marketing mix of internal marketing requires an analysis of the state of the organization and known degree of development of elements of marketing mix of internal marketing. This is followed by an explanation of each individual element of marketing mix of internal marketing and elaboration of the proposal of manner of implementation of each element within the organization. Definition and explanation of elements of marketing mix are followed by their implementation and, finally, control in the function of monitoring, correcting, developing and adjusting erroneous activities with the 
objective of providing feedback and insisting on constant improvement (Paliaga\&Strunje, 2011).

Significance of the Study

Finally, it is also important to remark that internal marketing activities achieve different levels of implementation when we compare organizations under public management models with organizations under innovative management models. It would be important for these organizations to learn how to develop and implement internal marketing strategies as this would be very much in keeping with the respective organizational. Objectives prevailing in terms of boosting effectiveness, efficiency, sustainability, and the provision of services quality (Azêdo\&Alves, 2014).As a result of this great effect of internal marketing, this study is geared to develop an internal marketing strategy foracademic field.

\section{AIM OF THE STUDY:}

To develop an internal marketing strategy for faculty of nursing at Port Said University.

\section{Study Objectives:}

1. Assess the availability of internal marketing elements among the teaching staff at the faculty of nursing, Port Said University.

2. Identify the availability of internal marketing elements among employees at the faculty of nursing, Port Said University.

3. Assess the availability of internal marketing elements among students at the faculty of nursing, Port Said University.

4. Develop an internal marketing strategy for the teaching staff, employees and students at the faculty of nursing, Port Said University based on the above-mentioned assessment.

\section{SUBJECTS AND METHOD:}

\section{Study Design \& Setting}

An explaratoryresearch design was used, carried out at the Faculty of Nursing in Port Said University.

\section{Study Sample}

The study populations have included all available internal customers of the faculty $(n=378)$, They divided into three groups:Teaching staff $(n=59)$ included (assistant professor (1), lecturers(26), assistant lecturers (14) and demonstrators (18), administrative staff (employees) $(n=68)$, and nursing students from second, third, and fourth academic years, in addition to the internship students $(n=251)$, after exclusion of 
the pilot study (41 internal customers ) from the entire sample size, with one year experiences at least in the studied faculty. And, the jury group to assess the developed strategy of internal marketing for Port Said Faculty of Nursing with total number of 39 experts.

TOOLS OF DATA COLLECTION: Data were collected by three questionnaire sheets to assess the availability of internal marketing elements among internal customers of the Faculty of Nursing, Port Said University. Internal marketing questionnaire was developed by Hussein (2009) based on Clark (1998); Elsayed (2005). There were some modifications done by the researcher in the light of literature review (Accreditation of Institutions of Higher Education for the Arab Republic of Egypt Guide, 2009) through adding items in different dimensions describing more details about support, empowerment, safety measures, communication, reward and benefits system and training.

\section{Tool (1):Internal Marketing among Nursing Teaching Staff}

.Tool (2):Internal Marketing among Employees.

Tool (3):Internal Marketing among Faculty of Nursing Students.

Tool (4): According to the results of the data assessment, an internal marketing strategy was developed to the Faculty of Nursing covering available internal customers of the Faculty (teaching staff, employees and students) as the fourth tool. It includes an introduction and historical overview of the faculty of Nursing; general framework of the internal marketing strategy of the Faculty of Nursing at Port Said University; achievement methodology of the internal marketing strategy achievement; stages of the strategy preparation; the systematic implementation of the strategy; methodology of strategy deployment; action plan of internal marketing strategy for the Faculty; follow-up mechanisms.

\section{Tool Content Validity and Reliability:}

The Structured Interviewing Questionnairewas tested for content validity by a panel ofeleven experts in the field of community health nursing and public health medicine. The reliability was assured by calculating cronbach's alpha coefficients for each factor, it was high (0.88). The validity of the developed strategy was measured through revising it by a panel of experts from Port Said faculty of nursing (dean, vices dean, heads of scientific nursing 
departments, heads of administrative departments, and heads of the students' union) and academic staff in the field of nursing administration from Alexandria, Ain Shams and Port Said Universities.

\section{Pilot study:}

A pilot study was undertaken before starting the data collection. It was carried out on 41studied personnel (9 teaching staff, 11 employees and 31 students). It was conducted at the time from 15th April 2015 to 14May 2015. The purpose of the pilot study was to test the applicability and the feasibility of the study tools. Also, it served to estimate the time needed to complete the data collection. In addition to find out any obstacles and problems that might interfere with data collection. The subjects included in the pilot study were excluded from the study subjects. The final form of the tool was formulated and the time needed for completing them was also determined.

\section{Administrative and Ethical Considerations:}

An official permission was obtained from the Faculty of Nursing to obtain the authorization for data collection. The aim of the study was explained to every internal customer before participation, and voluntary participation was emphasized and an oral consent was obtained.

\section{Statistical Analysis}

Data entry and statistical analysis were done using statistical package of social science (SPSS) version 16.0. Data were presented using descriptive statistics in the form of frequencies and percentages for determining the means the standard deviations and correlations for internal marketing elements for the teaching staff, employees and students at faculty of nursing in Port Said University.

\section{Field Work:}

After obtaining the official permission to conduct the study and after finalization of tools, the researcher met with the internal customers individually and explained to them the purpose of the study, the consent of each one were obtained before their participation. Data collection period extended three months from the beginning of May to the end of June 2015. Time needed for filling Questionnaire ranged from 20 to 30 minutes.An internal marketing strategy was developed based on assessment of the availability of the internal marketing elements among the internal customers (teaching staff, employees and students) of the faculty of nursing, Port Said University. 


\section{RESULTS}

\section{PART I: Internal Marketing among Nursing Teaching Staff}

Table (1): Personal and job characteristics of the teaching staff at the faculty of nursing, Port Said University. It was found that the mean age of the teaching staff was 32.9 years; the majority of the teaching staff were females $(98.3 \%)$; three quarters of the teaching staff was married (76.3\%); they are presented from six different scientific departments; less than half of the studied teaching staff were lecturers $(44.1 \%)$; the mean years of experience among nursing teaching staff was 9.8 years.

Table (2): The availability of internal marketing elements among the teaching staff at the Faculty of Nursing, Port Said University. It was found that more than two thirds (70.6\%) of the teaching staff was agree that the elements of internal marketing are applied in the faculty.Slightly more than half of teaching staff (52.5\%) was agree that the salary and benefits that are produced by the faculty satisfy their needs. While more than three quarters of them $(76.5 \%)$ was agreed about the communication in the faculty.

\section{PART II: Internal Marketing among Employees}

Table (3): Personal and job characteristics of the employees at the faculty of nursing, Port Said University. It was found that the mean age of the employees was 38.7 years; most of the employees $(70.6 \%)$ were females; $72.1 \%$ of them were married; they are presented ten different departments, $39.7 \%$ of the studied employees were $1^{\text {st }}$ degree of job rank; $11.8 \%$ have administrative positions; the experience duration means of employees participants was 13.1 years.

Table (4): The availability of internal marketing elements among employees at the Faculty of Nursing, Port Said University. It was found that $62.3 \%$ of the employees were agreeing that the elements of IM are applied in the faculty.Only $43.5 \%$ was agreeing that the salary and benefits that are produced by the faculty satisfy their needs. While more than two third of them $(69.1 \%)$ was agreed about the communication in the faculty.

\section{PART III: Internal Marketing among Nursing Students}

Table (5): Personal characteristics of the students at the faculty of nursing, Port Said University. It was found that mean age of students was 21.5 years; $62.9 \%$ of students 
were females: they are presented three different academic years in addition to internship year.

Table (6): The availability of internal marketing elements among the students at the Faculty of Nursing, Port Said University. It was found that $69.5 \%$ of students were agreeing that elements of IM are applied in faculty. While more than two third (68.2\%) of students was agreeing that benefits that are produced by faculty satisfy their needs. And $72.1 \%$ of them were agreeing about communication in faculty.

\section{PART IV: Internal marketing strategy}

Table (7):shows agreement upon the face and content validity of the developed strategy among the experts team. As indicated in the table, the entire experts group assured that the proposed strategy looks structurally like internal marketing strategy and its parts looks in a good logical sequence. While $85.7 \%$ of them assured that the wording (writing) of the proposed strategy is sound (no mistakes), and $88.5 \%$ stated the strategy has suitable illustrations.

Table (1): Personal and job characteristics of the teaching staff at Port Said' Faculty of Nursing

\begin{tabular}{|l|l|l|}
\hline \multirow{2}{*}{ Personal and job characteristics } & \multicolumn{2}{l|}{ Teaching staff (n=59) } \\
\cline { 2 - 3 } & No. & \% \\
\hline Personal characteristics & \multicolumn{2}{l|}{} \\
\hline Age (years)Min-Max & $23.0-50.0$ \\
\hline Mean \pm SD & $32.9 \pm 7.2$ \\
\hline GenderMale & 1 & 1.7 \\
\hline Female & 58 & 98.3 \\
\hline Marital statusSingle & 11 & 18.6 \\
\hline Married & 45 & 76.3 \\
\hline Divorced & 3 & 5.1 \\
\hline Occupational characteristics & \multicolumn{2}{|l|}{} \\
\hline SpecialtyNursing Administration & 7 & 11.9 \\
\hline Obstetrics and gynecology nursing & 14 & 23.7 \\
\hline Pediatrics nursing & 8 & 13.6 \\
\hline Community health nursing & 8 & 13.6 \\
\hline Medical and surgical nursing & 18 & 30.5 \\
\hline Psychiatry nursing & 4 & 6.8 \\
\hline Academic rank Demonstrator & 18 & 30.5 \\
\hline Assistant lecturer & 14 & 23.7 \\
\hline Lecturer & 26 & 44.1 \\
\hline Assistant professor & 1 & 1.7 \\
\hline Duration of experience (years)Min-Max & $1.0-25.0$ & \\
\hline Mean \pm SD & $9.8 \pm 6.9$ & \\
\hline
\end{tabular}


Table (2): All elements of internal marketing among teaching staff at Port Said' Faculty of Nursing.

\begin{tabular}{|l|l|l|l|}
\hline Elements & Min & Max & Mean \pm SD \\
\hline Policy and administration & 42.0 & 98.0 & $72.0 \pm 11.4$ \\
\hline Salary and benefits & 20.0 & 78.2 & $52.5 \pm 11.9$ \\
\hline Supervision & 40.0 & 100.0 & $75.1 \pm 13.4$ \\
\hline Communication & 26.7 & 100.0 & $76.5 \pm 13.2$ \\
\hline Training and advancement & 26.7 & 100.0 & $72.8 \pm 16.8$ \\
\hline job description & 20.0 & 100.0 & $72.9 \pm 16.9$ \\
\hline Achievement and rewards & 32.0 & 98.0 & $63.9 \pm 14.9$ \\
\hline Institutional support & 30.0 & 100.0 & $70.9 \pm 13.7$ \\
\hline Safety measures & 32.7 & 100.0 & $72.1 \pm 13.7$ \\
\hline Scientific research support & 26.5 & 100.0 & $73.2 \pm 13.6$ \\
\hline $\begin{array}{l}\text { Administrative support and } \\
\text { recognition }\end{array}$ & 28.6 & 100.0 & $71.9 \pm 15.4$ \\
\hline Empowerment & 28.5 & 100.0 & $68.7 \pm 15.6$ \\
\hline Total score (\%): Mean \pm SD & & & $70.6 \pm 12.1$ \\
\hline
\end{tabular}

Table (3): Personal and job characteristicsof the employees at Port Said' Faculty of Nursing.

\begin{tabular}{|c|c|c|}
\hline \multirow{2}{*}{ Personal and job characteristics } & \multicolumn{2}{|c|}{ employees $(n=68)$} \\
\hline & No. & $\%$ \\
\hline \multicolumn{3}{|l|}{ Personal characteristics } \\
\hline Age (years):Min-Max & \multicolumn{2}{|l|}{$22.0-58.0$} \\
\hline Mean \pm SD & \multicolumn{2}{|l|}{$38.7 \pm 10.2$} \\
\hline Gender:Male & 20 & 29.4 \\
\hline Female & 48 & 70.6 \\
\hline Marital status:Single & 13 & 19.1 \\
\hline Married & 49 & 72.1 \\
\hline Divorced/widow & 6 & 8.8 \\
\hline \multicolumn{3}{|l|}{ Occupational characteristics } \\
\hline Specialty:Technical affair & 31 & 45.6 \\
\hline Purchase affair & 10 & 14.7 \\
\hline Administrative affair & 3 & 4.4 \\
\hline Youth care affair & 2 & 2.9 \\
\hline Postgraduate affair & 2 & 2.9 \\
\hline Library & 3 & 4.4 \\
\hline Financial affairs & 6 & 8.8 \\
\hline Stores & 1 & 1.5 \\
\hline Undergraduate affairs & 7 & 10.3 \\
\hline Salaries & 3 & 4.4 \\
\hline job rank: $1^{\text {st }}$ degree & 27 & 39.7 \\
\hline $2^{\text {nd }}$ degree & 11 & 16.2 \\
\hline $3^{\text {rd }}$ degree & 21 & 30.9 \\
\hline $4^{\text {th }}$ degree or more & 9 & 13.2 \\
\hline Administrative position: & 60 & 88.2 \\
\hline Present & 8 & 11.8 \\
\hline
\end{tabular}




\begin{tabular}{|l|l|}
\hline $\begin{array}{l}\text { Duration of experience (years): Min- } \\
\text { Max }\end{array}$ & $1.0-29.0$ \\
\hline Mean \pm SD & $13.1 \pm 8.4$ \\
\hline
\end{tabular}

Table (4): All elements of internal marketing among employees at Port Said' faculty of nursing.

\begin{tabular}{|l|l|l|l||}
\hline Elements & Min & Max & Mean \pm SD \\
\hline Policy and administration & 35.6 & 95.6 & $63.4 \pm 12.4$ \\
\hline Salary and benefits & 20.0 & 80.0 & $43.5 \pm 15.7$ \\
\hline Supervision & 28.6 & 100.0 & $67.8 \pm 14.9$ \\
\hline Communication & 25.7 & 100.0 & $69.1 \pm 11.9$ \\
\hline Training and advancement & 26.7 & 100.0 & $60.6 \pm 15.4$ \\
\hline job description & 28.0 & 100.0 & $64.0 \pm 15.3$ \\
\hline Achievement and rewards & 22.0 & 100.0 & $56.6 \pm 14.3$ \\
\hline Institutional support & 20.0 & 100.0 & $66.8 \pm 13.4$ \\
\hline Safety measures support and & 32.7 & 100.0 & $67.1 \pm 13.7$ \\
\hline $\begin{array}{l}\text { Administrative } \\
\text { recognition }\end{array}$ & 20.0 & 100.0 & $66.5 \pm 15.4$ \\
\hline Empowerment & 20.0 & 100.0 & $60.4 \pm 14.4$ \\
\hline Total score $(\%):$ Mean \pm SD & & $62.3 \pm 11.4$ \\
\hline
\end{tabular}

Table (5): Personal characteristics of students at faculty of nursing in Port Said University.

\begin{tabular}{|l|l|l|}
\hline \multirow{2}{*}{ Personal characteristics } & \multicolumn{2}{l|}{ Students $(\mathbf{n = 2 5 1})$} \\
\cline { 2 - 3 } & No. & \% \\
\hline Personal characteristics & \multicolumn{2}{|l|}{} \\
\hline Age (years):Min-Max & $19.0-24.0$ \\
\hline Mean \pm SD & $21.5 \pm 1.1$ & 37.1 \\
\hline Gender:Male & 93 & 62.9 \\
\hline Female & 158 & 40.6 \\
\hline Academic year:2 ${ }^{\text {nd }}$ & 102 & 24.3 \\
\hline $3^{\text {rd }}$ & 61 & 23.5 \\
\hline $4^{\text {th }}$ & 59 & 11.6 \\
\hline Internship year & 29 & \\
\hline
\end{tabular}

Table (6): All elements of internal marketing among students at Port Said' Faculty of Nursing.

\begin{tabular}{||l|l|l|l||}
\hline Elements & Min & Max & Mean \pm SD \\
\hline Policy and administration & 22.2 & 100.0 & $70.5 \pm 19.3$ \\
\hline Benefits & 28.0 & 100.0 & $68.2 \pm 20.1$ \\
\hline Supervision & 24.4 & 100.0 & $70.7 \pm 18.6$ \\
\hline Communication & 20.0 & 100.0 & $72.1 \pm 18.0$ \\
\hline Training and advancement & 20.0 & 100.0 & $69.8 \pm 19.7$ \\
\hline Achievement and rewards & 20.0 & 100.0 & $70.7 \pm 19.4$ \\
\hline Institutional support & 20.0 & 100.0 & $68.7 \pm 20.2$ \\
\hline \hline
\end{tabular}




\begin{tabular}{||l|l|l|l||}
\hline Safety measures & 20.0 & 100.0 & $68.5 \pm 20.8$ \\
\hline Administrative support and recognition & 20.0 & 100.0 & $68.5 \pm 21.4$ \\
\hline Empowerment & 20.0 & 100.0 & $69.2 \pm 20.8$ \\
\hline Total score (\%): Mean \pm SD & & $69.5 \pm 18.6$ \\
\hline
\end{tabular}

Table (7): Agreement upon the face validity of the developed strategy among the experts team.

\begin{tabular}{|l|l|l||}
\hline Items & No. & $\%$ \\
\hline The proposed strategy looks structurally like internal & & \\
marketing strategy: & 35 & $100 \%$ \\
The size (number of pages) is suitable & 35 & $100 \%$ \\
It has accurate out line & 35 & $100 \%$ \\
It has general introduction & & \\
\hline The proposed strategy is divided into parts which look: & & \\
In good logical sequence & 35 & $100 \%$ \\
Having no gaps & 33 & $94.2 \%$ \\
Having no overlaps (repetition) & 32 & $91.4 \%$ \\
\hline The wording (writing) of the proposed strategy is: & 32 & $91.4 \%$ \\
Clear (easily understandable) & 33 & $94.2 \%$ \\
Interesting & 30 & $85.7 \%$ \\
Sound (no mistakes) & 32 & $91.4 \%$ \\
With no redundancy (repetitions) & 31 & $88.5 \%$ \\
The strategy has suitable illustrations &
\end{tabular}

\section{DISCUSSION:}

Internal marketing is based on seeing work force as internal customers, while activities and work tasks are seen as internal products to meet needs and desires of internal and external customers to achieve organization objectives. Internal marketing concept focused on continuous improvement of internal customers and their understanding of the organization for which they work (Mishara, 2010; Paliaga\&Strunje, 2011). So, this study was conducted to develop an internal marketing strategy for Faculty of Nursing at Port Said University through assessing of the availability of internal marketing elements among their teaching staff, employees and students at the Faculty of Nursing, Port Said University.

The experts' jury opinions asserted that the proposed strategy looks structurally like internal marketing strategy and its parts lookin a good logical sequence, with sound writing (no mistakes), and it has suitable illustrations. In this regard Bottary (2011) stated that the strategy should have clarity of purpose and realistic goals, understanding internal customers' culture, transparent, monitoring, measurement and 
feedback.Additionally, the experts' jury opinions asserted that the proposed strategy determined the gap between the present internal marketing situation in the faculty and what was supposed to be and how to achieve it. Through enhancing all elements of benefits and empowerment to all internal customers; enhancing sense of achievements and rewards to teaching staff and employees; enhancing the health and safety measures, administrative support and recognition for the faculty students; enhancing work policies of the teaching staff; enhancing levels and forms of training in the faculty to their employees and students. On the other hand the faculty has to enforce their efforts in the communication process among all faculty' internal customers, and supervision and support of the scientific research process for the teaching staff.

Regarding the total availability of total internal marketing elements at the faculty of nursing, Port Said University, the findings indicated that availability of internal marketing elements among teaching staff is the highest total of availability, followed by students and employees. Also, the finding revealed that the communication element is the highest one among all internal customers (teaching staff, employees and students), followed by supervision and scientific research support among teaching staff, supervision and safety measures among employees and supervision and achievement and rewards among students. This finding supported byTsai (2014) who concluded that communication channels between the managers and staff should be strengthened to clearly convey the vision and goals to frontline employees.And Falender and Shafranske (2012) who clarified that organization has to establish the supervisory relationship by satisfying the roles, tasks, responsibilities of supervisee and supervisor. This may be due to the advanced method of teaching that the faculty use, which help in increasing the availability of communication and supervision elements. Also,Chepkwony and Oloko (2014)concluded that management should ensure that reward system is effective enough and competitive to influence internal customers to work harder.

The experts' jury opinions asserted that the internal marketing strategy asserted that the faculty has to strengthen their efforts on professional and social communications in the faculty through holding regular meetings with internal customers to communicate vision, mission and goals of the faculty; holding regular meeting with internal customers to make any change or amendment in policy, goals or the educational process; holding regular seminars on how to deal with labor and study conflicts and active communications; establish plans including all internal customers to community services 
as workshops and cultural seminars; holding non educational activities including all internal customer like faculty fun day, short messages day, uniform's day, sportive activities day, fieldtrips, art day and collectively food day.

Whereas, the lowest total of availability element of internal marketing among all internal customers of the faculty is the benefits. This may be due to limited resources of the small and newly Port Said University lead to low level of benefits. The current study findings indicated that the majority of teaching staff and employees stated that the faculty administration does not provide a nursery in the faculty, no means of transportations for teaching staff and no opportunity for foreign secondment for employees, which about half of the students of the faculty asserted that faculty administration provides means of transportations, housing of expats, place for students break as cafeteria. This finding is in congruent with Chepkwony and Oloko (2014) who recommended that internal customer's benefits is not competitive enough. While, Ramos (2015) stated that organizations should update internal customer' fringe benefits to keep abreast with the current trends on internal customer needs and motivation. This would mean that Port Said faculty of nursing need to develop new forms of benefits to increase level of satisfaction of the internal customers.

The experts' jury opinions asserted that the internal marketing strategy concluded that the faculty has to provide a suitable and attractive system of benefits to their internal customers as provide opportunities for scientific missions, cultural exchange and grants to work and study abroad, provide recreational trips supported by the faculty on a regular basis; create a nursery or contract with one of the neighboring nurseries of the faculty to care for children of teaching staff and employees; address the university administration to provide a means of transport or contracting with a public transport companies to transport expatriate internal customers; provide business corporation protocols with the services in the community surrounding the faculty such as private hospitals or recreational clubs; address the university administration to provide a special administrative housing for expats and their families or contracting with the housing associations; improve the performance of the cafeteria to be suitable for a break for the internal customers; provide financial support for those wishing to practice various sports.

In general, organization which can develop its strategy will get a champion in competition; it can be a winner in the competition if they collaborate each other between the human capital and technological support that will execute strategy to create satisfaction in terms of both internal and external customers (Susanti et al., 2015). So 
finally,managers need to be more proactive trying to introduce the marketing function in human capital issues. Understanding internal customers' wants and needs and selling internally responsibility goals would make external efforts in developing a responsible strategy much more likely to succeed (Sanchez-Hernandez \& Grayson, 2012).

\section{CONCLUSION:}

It was concluded that availability of internal marketing elements at the faculty of nursing, Port Said University is moderately fulfilled. The highest mean score of internal marketing availability was among the teaching staff followed by students and employees. The most available element of the internal marketing among the three categories (teaching staff, employees and students) is the communication element, followed by supervision and scientific research support among teaching staff, supervision and safety measures among employees and supervision followed by achievement and rewards among students. Whereas, the lowest available element is the benefits among teaching staff, employees and students.

\section{RECOMMENDATIONS:}

The faculty administration has to develop an internal marketing strategy and take needed measures towards increasing the availability of internal marketing elements among their internal customers (teaching staff, employees and students) through: improving all attributes of benefits, pay, rewards, empowerment, support, and training and safety measures. And energize all attributes of supervision and communication. Also faculty administration has to regularly assess the availability of internal marketing elements among their internal customers.

\section{REFERENCES:}

Accreditation of institutions of higher education for the Arab republic of Egypt, (2009).Guide of Accreditation of institutions of higher education for the Arab republic of Egypt.

Ahmed, P. \&Rafiq, M. (2003).Internal marketing issues and challenges.European journal of marketing, 37(9), 1177-1186. Available online at http://www.emeraldinsight.com/ 
Azêdo, D. \&Alves, H. (2014).Internal marketing practices in health care and their influence on nurse motivation: public versus nonpublic management models. Home health care management \& practice, 26(2), 92-100. Available at www.hhc.sagepub.com

Bottary, L., (2011). Top 10 attributes of successful strategic plans.Available online athttps://www.americanexpress.com/us/small-business/

Cătălin, M., Andreea, P. \& Adina, C. (2014).A holistic approach on internal marketing implementation.Business Management Dynamics, 3(11), 9-17.

Chepkwony, C. \&Oloko, M. (2014).The relationship between rewards systems and job satisfaction, a case study at teachers' service commission- Kenya.European journal of business and social sciences, 3(1), 59-70. Available at http://www.ejbss.com/recent.aspx

Clark, C. (2008). Student perspectives on faculty incivility in nursing education: An application of the concept of rankism. Nursing outlook, 56(1), 4-8. Available online at https://www.ncbi.nlm.nih.gov/pubmed

Falavarjani, M. M., Falavarjani, A.M., \&Isfahani, A.N. (2013).Investigate the relation between internal marketing and organizational learning (Case Study: Telecommunication Company of Isfahan). International journal of academic research in business and Social Sciences, 3(12), 634-644. Available online at http://hrmars.com/

Falender, C. \&Shafranske, E. (2012).Clinical Supervision: A Competency-Based Approach. (2 $2^{\mathrm{ST}} \mathrm{ed}$.), American psychological association, USA.

Kanibira, H., Nartb, S. (2012). The effects of internal relationship marketing on superior customer relations as competitive performance: Evidence from healthcare industry. The $8^{\text {th }}$ International strategic management conference, Procedia - Social and Behavioral Sciences, 58 (1), 1378-1385. Available online at www.sciencedirect.com

Kokemuller, N. (2015). What is the meaning of internal marketing?. Available online at http://www.ehow.com/info 
Mishra, S. (2010).Internal marketing- A tool to harness employees' power in service organizations in India.International journal of business and management, 5(1), 185-193.Available online at http://www.ccsenet.org/journal/index.php/ijbm/index

Mutharasu, S., Natarajan, K. \& Filipe, J. (2013).Effect of internal-marketing-mix on customer-pyramid-oriented banking service performance, An Indian Experience.International journal of latesttrends Fin. Eco. Sc., 3(3), 583-593.

Paliaga, M. \&Strunje, Z. (2011).Research of implementation of internal marketing in companies in the republic of Croatia.Economic researchEkonomskaistraživanja, 24(1), 107-121.Available online at http://www.tandfonline.com/toc/rero20/24/1?nav=tocList\#

Ramos, J. (2015). Internal marketing (IM) dimensions and organizational commitment (OC) of universal banks' employees.Proceedings of the Second AsiaPacific Conference on Global Business, Economics, Finance and Social Sciences (AP15Vietnam Conference), Danang, Vietnam, 10-12 July 2015.

Sanchez- Hernancez, I. \& Grayson, D. (2012).Internal marketing for engaging employees on the corporate responsibility journey. Intangible Capital, 8(2): 275307.http://dx.doi.org/10.3926/ic.305

Shahzad,T. \&Naeem, H. (2013).Role of internal marketing in employee engagement leading to job satisfaction of employees in private banks of Pakistan.Journal of Business and Management, 8(2), 62-68.

Shamma, H. (2012).Exploring Internal Marketing Applications: Case of Egypt. Journal of marketing development \& competitiveness, 6(4), 116-125. Available online athttp://www.na-businesspress.com/Subscriptions/

Shima, B. \& George, B. (2014).Strategies for the development of internal marketing orientation in the private high education institutions in Albania.Academic journal of interdisciplinary studies,3(3), 393.Available online athttp://www.mcser.org/journal/index.php/ajis/ issue/view/71

Susanti, E., Sule, E. \&Sutisna, H. (2015).The Impact of internal and external service quality, A Case study among lecturers and students.Mediterranean journal of 


\begin{tabular}{llllll}
\hline social sciences, & $6(5$, & S5), & $77-83$. & Available & online
\end{tabular}
athttp://www.mcser.org/journal/index.php/mjss/article/view/ 7879/7545

Tsai, Y. (2014).Learning organizations, internal marketing, and organizational commitment in hospitals.BMC health service research, 14(152), 1-8. Available at http://download.springer.com/

Warraich, A., Awais, M., Parkash, R. \& Ahmad, B. (2014). Internal marketing: An application of principal component analysis. Available online at

Yashar, A., Soleyman, I. \& Hussein, J. (2013). Effective internal strategic factors on customer satisfaction from the perspective of organization's managers in Tabriz travel agencies.Research journal of recent sciences, 2(9), 40-46. Available online athttp://www.isca.in/rjrs/v2i9.php

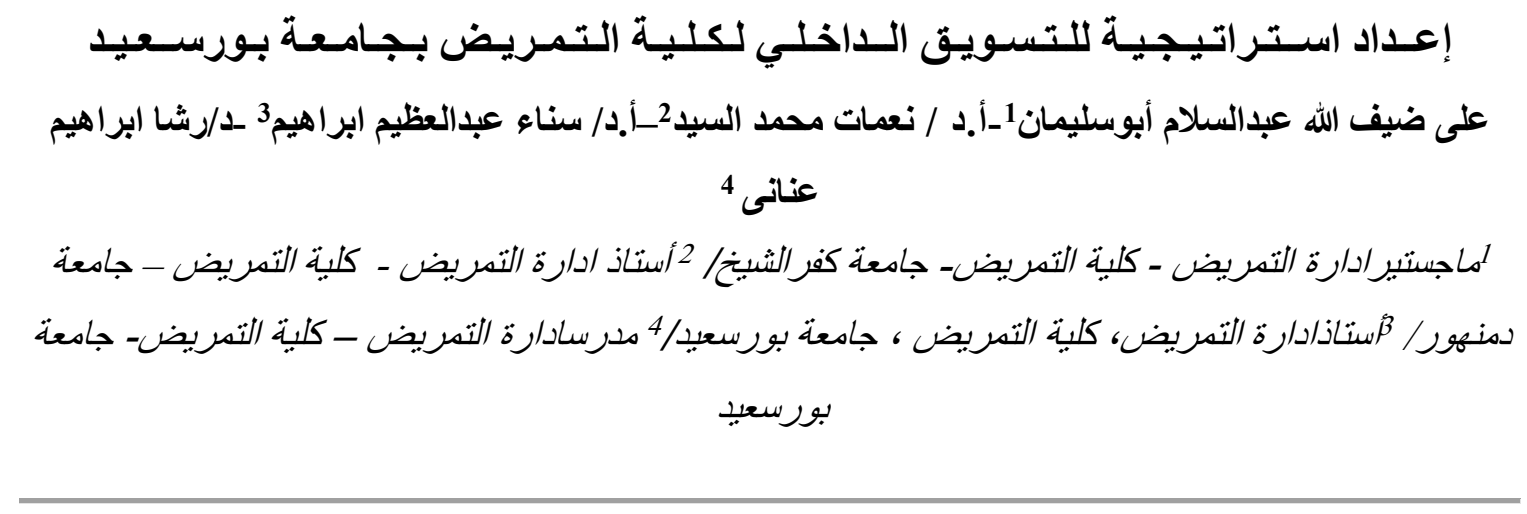

\section{الـخلاصة}

إن للتسويق الداخلى للمؤسسات تأثثر ملحوظ على التسويق الخارجى لها، لذا كان هدف الدر اسـة هو اعداد استر اتيجية

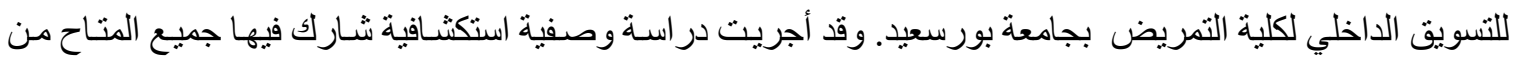
هيئة التدريس وموظفين وطلاب الكلية خلال العام الدراسي 2016/2014، ولقد شـارك فى البحث عدد 378 يمثلون الفئات الثلاث ، تم استخدام ثلاثذة استنيانات لقيـاس مدى تو افر عناصـر التسويق الداخلي بين أعضـاء هيئة التدريس

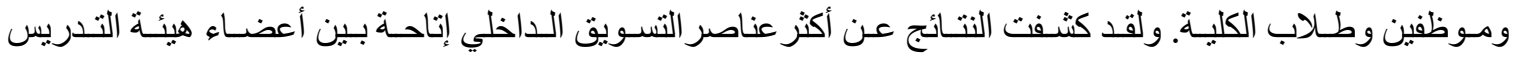
و الموظفين و الطلاب هو التواصل، يليه الإثر اف ودعم البحث العلمي بين هيئة التدريس، والإشر اف و السـلامة المهنية بين الموظفين، و الإثر اف ومستوى الإنجاز و المكافآت بين طلاب الكلية. فى حين أن المنافع كانت الأقل إتاحة لكل من هيئة التدريس و الموظفين و الطلاب. نستخلص من الدر اسـة أن مدى اتاحة عناصر التسويق الداخلى فى كلية التمريض بجامعة بورسعيد هى متو اضعة. و لذلك يوصى بأنه يجب على قيادات الكلية العمل على تعظيم جهودها واتخـاذ التدابير اللازمة نحو نطبيق استر اتيجية التسويق الداخلي.

الكلفـات الســـشــة : التسويق الداخلي، المستهلك الداخلي، الهيئة التدريسية، الطلاب، الموظفين 